Article

\title{
Estimation of Greenhouse Gas Emission from Hanwoo (Korean Native Cattle) Manure Management Systems
}

\author{
Seunggun Won ${ }^{1}$, Youngbin Yoon ${ }^{1}$, Muhammad Mahboob Ali Hamid ${ }^{1}{ }^{\oplus}$, Arif Reza ${ }^{2,3}{ }^{\circledR}$, \\ Soomin Shim ${ }^{2}$, Seungsoo Kim ${ }^{2}$, Changsix $\mathrm{Ra}^{2}{ }^{2}$, Eliza Novianty ${ }^{2}$ and Kyu-Hyun Park ${ }^{2, *}$ \\ 1 Department of Animal Resources, College of Life and Environmental Science, Daegu University, \\ Gyeongsan 38453, Korea; swon@daegu.ac.kr (S.W.); lucidity7@naver.com (Y.Y.); \\ drmahboobali09@yahoo.com (M.M.A.H.) \\ 2 Department of Animal Industry Convergence, College of Animal Life Sciences, Kangwon National \\ University, Chuncheon 24341, Korea; reza.arif@kangwon.ac.kr (A.R.); smshim@kangwon.ac.kr (S.S.); \\ seungsoo89@kangwon.ac.kr (S.K.); changsix@kangwon.ac.kr (C.R.); elizanovianty@gmail.com (E.N.) \\ 3 Department of Environmental Science, College of Agricultural Sciences, IUBAT-International University of \\ Business Agriculture and Technology, Dhaka 1230, Bangladesh \\ * Correspondence: kpark74@kangwon.ac.kr; Tel.: +82-33-250-8621
}

Received: 19 June 2020; Accepted: 6 August 2020; Published: 10 August 2020

\begin{abstract}
The agricultural sector is considered one of the major sources of greenhouse gas (GHG) emissions globally. The livestock industry as a significant contributor, is accounting for about $18 \%$ of GHG emissions measured in carbon dioxide $\left(\mathrm{CO}_{2}\right)$ equivalent from agricultural practices. Depending on farming practices and climatic conditions, GHGs such as methane $\left(\mathrm{CH}_{4}\right)$ and nitrous oxide $\left(\mathrm{N}_{2} \mathrm{O}\right)$ emissions from livestock agriculture can vary significantly. Country-specific emission factors are, therefore, needed for a precise estimation of GHG emissions and to avoid uncertainties. This study was aimed at estimating the $\mathrm{CH}_{4}$ and $\mathrm{N}_{2} \mathrm{O}$ emission fluxes from Hanwoo (the most famous and popular Korean native cattle) manure management systems. $\mathrm{CH}_{4}$ and $\mathrm{N}_{2} \mathrm{O}$ emission fluxes from litter in the Hanwoo cattle barn and composting lot were monitored and calculated for 52 weeks using the dynamic chamber method. The calculated monthly average fluxes of $\mathrm{CH}_{4}$ and $\mathrm{N}_{2} \mathrm{O}$ from litter in the cattle barn ranged from 0.0 to $30.0 \pm 13.7$ and $0.896 \pm 0.557$ to $2.925 \pm 2.853 \mu \mathrm{g} / \mathrm{m}^{2} \mathrm{~s}$, respectively during the whole measurement period. While during the composting period, the monthly average of $\mathrm{CH}_{4}$ and $\mathrm{N}_{2} \mathrm{O}$ emission fluxes were varied from $1.449 \pm 0.783$ to $86.930 \pm 19.092$ and $0.511 \pm 0.410$ to $2.629 \pm 1.105 \mu \mathrm{g} / \mathrm{m}^{2} \mathrm{~s}$, respectively. The calculated emission fluxes of $\mathrm{CH}_{4}$ and $\mathrm{N}_{2} \mathrm{O}$ from manure management systems in this study were almost 5.4 and 2.1 times, respectively higher than the values reported for the Asian, South and North American countries in the 2006 Intergovernmental Panel on Climate Change (IPCC) Guidelines for National Greenhouse Gas Inventories. Overall, this study initiates the process along with signifies the importance of developing country-specific GHG inventories for the effective reduction of GHG emissions from the livestock sector in Korea.
\end{abstract}

Keywords: greenhouse gas; $\mathrm{CH}_{4} ; \mathrm{N}_{2} \mathrm{O}$; Hanwoo cattle; livestock; manure management; Korea

\section{Introduction}

Climate change has been one of the most significant and widely discussed challenges during the last few decades worldwide, with extreme weather patterns, sea level rise, change in ocean currents, and melting icecaps and glaciers [1]. Global climate change caused by greenhouse gas (GHG) emissions has been constantly illustrated with balances of nutrients in the agricultural setting. The livestock industry as a major contributor, is responsible for about $18 \%$ of GHG emissions measured in carbon 
dioxide $\left(\mathrm{CO}_{2}\right)$ equivalent from the agricultural sector [2]. The 2006 Intergovernmental Panel on Climate Change (IPCC) guideline (GL) recognizes both $\mathrm{CH}_{4}$ and $\mathrm{N}_{2} \mathrm{O}$ gases as significant GHGs in the livestock sector and their impact on global warming [3]. $\mathrm{CH}_{4}$ and $\mathrm{N}_{2} \mathrm{O}$ have a global warming potential of 28-36 and 265-298 times that of $\mathrm{CO}_{2}$ over 100 years, respectively [4]. According to Food and Agriculture Organization (FAO), the livestock industry emits $37 \%$ of anthropogenic $\mathrm{CH}_{4}$ mainly from ruminant enteric fermentation, and $65 \%$ of anthropogenic $\mathrm{N}_{2} \mathrm{O}$ from manure management [1].

Gaseous emissions from livestock agriculture are generally affected by environmental conditions, ventilation rate, dietary composition, animal activities, animal life stage, manure properties (e.g., moisture content and $\mathrm{pH}$ ), and manure management practices [5,6]. To measure GHG emissions, chamber-based (manual or automated) and micrometeorological (eddy covariance or gradient techniques) methods are generally used [3], while a combination of both approaches can also be adopted [7]. Compared to micrometeorological techniques, chamber-based techniques are widely used due to their simplicity, low operational cost and convenience [8]. However, chamber-based methods typically only cover short time intervals and have the drawback of biasing the environmental conditions known to affect GHG exchange such as temperature and humidity [3]. Over nearly a century, chamber measurements of trace gas fluxes between the surface of the ground and the atmosphere were carried out. Various chamber methods, including static (closed chamber/non-flow-through chamber) and dynamic (open chamber/flow-through chamber), are used to estimate GHG $\left(\mathrm{CO}_{2}, \mathrm{CH}_{4}, \mathrm{~N}_{2} \mathrm{O}\right)$ fluxes with varying degrees of success $[9,10]$. Between the chamber techniques, the majority of studies used static chambers to measure the GHG emissions [11]. In a static chamber, the concentration of gas within the chamber increases over time because there is very little or no substitution of air in the headspace. Jørgensen et al., therefore, used fans to blend the air in the headspace to reduce bias from gradients of the vertical gas concentration [12]. On the other hand, in a dynamic chamber, continuous flow of outside air is maintained and the difference in concentration between entering and leaving air is measured. The continuous external airflow in the dynamic chambers helps to maintain a steady-state gas concentration gradient at the surface-air interface, hence, the GHG emissions can be measured uninterruptedly $[13,14]$.

In Korea (hereafter referred as Korea), emissions from agricultural activities accounted for $3 \%$ of Korea's total GHG emissions in 2013, showing a marginally higher increase when compared with 2006 (2.5\%) $[15,16]$ and as main contributors, $\mathrm{CH}_{4}$ and $\mathrm{N}_{2} \mathrm{O}$ represented $20 \%$ and $13 \%$ of the total emission from the agriculture sector [17]. Ji and Park reported that enteric $\mathrm{CH}_{4}$ emissions, $\mathrm{CH}_{4}$ and $\mathrm{N}_{2} \mathrm{O}$ emissions from livestock manure management in Korea showed annual growth rates of $1.7 \%, 2.6 \%$ and $3.2 \%$, respectively from 1990 to 2009 [18]. The Korean government recently announced a roadmap to decrease the GHG emissions by 2030 [19], which proposed a reduction in overall GHG emissions from the agriculture sector by $5.2 \%$. Currently, Korea is applying Tier 1 methods in IPCC 1996 GL to calculate GHG emissions livestock industries and planning to use 2006 GL by 2023 . However, for a precise estimation of GHG emissions and to avoid uncertainties, the IPCC 2006 GL recommends each country to develop country-specific emission factors (EFs).

Korea is one of the countries having limited grazing land for ruminants, due to a shortage in arable lands and increased pressure on agricultural production. Moreover, over the past few decades, the dietary pattern of Korean people has changed from rice to animal products including meat, milk and eggs. Additional livestock products are, therefore, needed to fulfil growing demand, which ultimately leads to a rise in GHG emission levels from livestock agriculture. Hanwoo (Bos primigenius), the most dominant Korean native cattle are raised to meet beef production needs. According to the Hanwoo traceability system, the number of cattle amounted to 3.07 million in 2019 , representing more than $86 \%$ of the total cattle population in Korea [20]. Hanwoo cattle has been identified as the major contributor of the GHG emissions from the cattle production sector in Korea as well as showed higher enteric GHG emissions than other breeds [21,22]. However, none of the studies have estimated GHG emissions from Hanwoo cattle manure management systems, which acts as the main hindrance to developing national GHG emissions statistics for livestock sector in Korea. Considering the above, this study was, 
therefore, aimed at investigating the $\mathrm{CH}_{4}$ and $\mathrm{N}_{2} \mathrm{O}$ emission fluxes from the Hanwoo cattle manure management systems using the dynamic chamber method.

\section{Experiments}

\subsection{Research Site and Description}

This research was conducted from 2 November 2018 to 1 November 2019 (365 days; 52 weeks; 93 times sampling) at the Kangwon National University Annex Farm ( $37^{\circ} 56^{\prime} 24.1^{\prime \prime} \mathrm{N}$ and $\left.127^{\circ} 46^{\prime} 57.0^{\prime \prime} \mathrm{E}\right)$ located in Chuncheon, Korea. During the study, 46 Hanwoo cattle between the ages of 0 and 108 months were reared in a steel-made winch-curtain barn $\left(1071 \mathrm{~m}^{2}\right)$. Sawdust was used as bedding with $\pm 10 \mathrm{~cm}$ of thickness at the beginning. A total of 24 pens were used in this study. Each pen had one to four cattle filled in with ad libitum water supply except the pen located in the bottom left (Figure 1, cross marked), which was used for storing the silage. The housed cattle were fed with roughage, pellets, and concentrates twice a day (09:00 and 17:00).

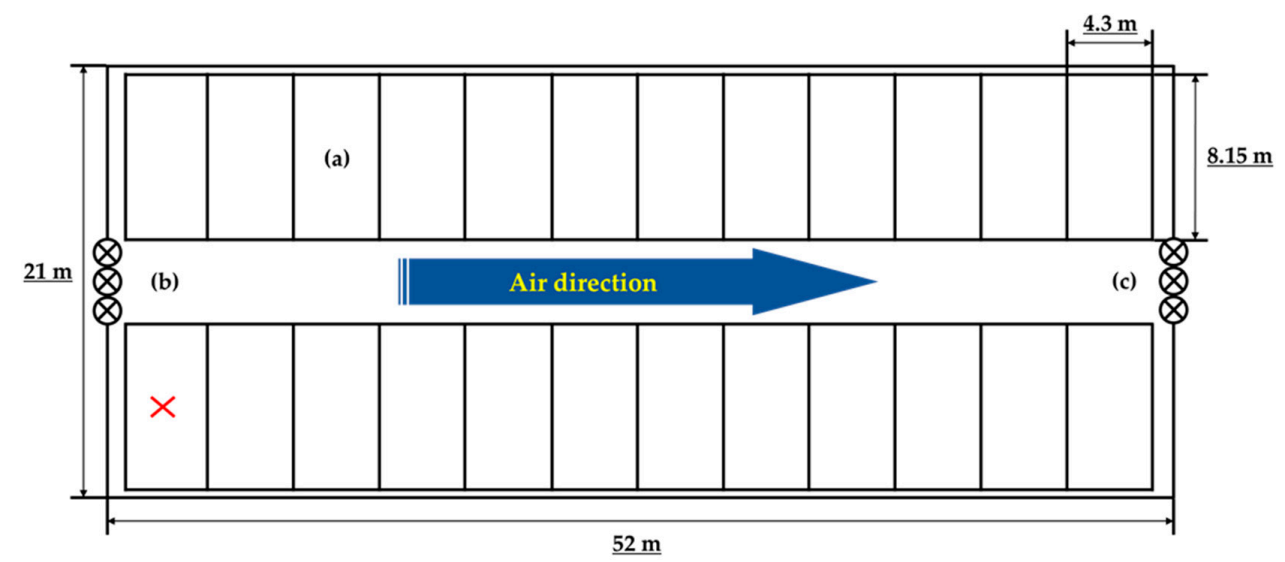

Figure 1. Overview of the cattle barn: (a) cattle pen, (b) inlet fan, (c) outlet fan.

\subsection{Chamber Installation, Composting Facility and Data Recording}

The surface area of the cattle rearing barn was $736 \mathrm{~m}^{2}$ and as a dynamic chamber, the barn was sealed and the fans were placed in front and back of the barn for continuous airflow. Three fans were fixed at the center above the main entrance (Figure 1). Airflow rate from the fan was measured with an air flow capture hood or balometer.

In the present study, the $\mathrm{CH}_{4}$ and $\mathrm{N}_{2} \mathrm{O}$ emissions from the composting lot was measured using a mega-dynamic chamber. The entire composting lot was covered and equipped with fans for air inflow and outflow similar to the cattle barn GHG estimation system. Figure 2 represents the schematic of the composting facility. Most farms in Korea operate static pile for composting. Hence, the composting facility was designed to simulate composting as close as in practice.
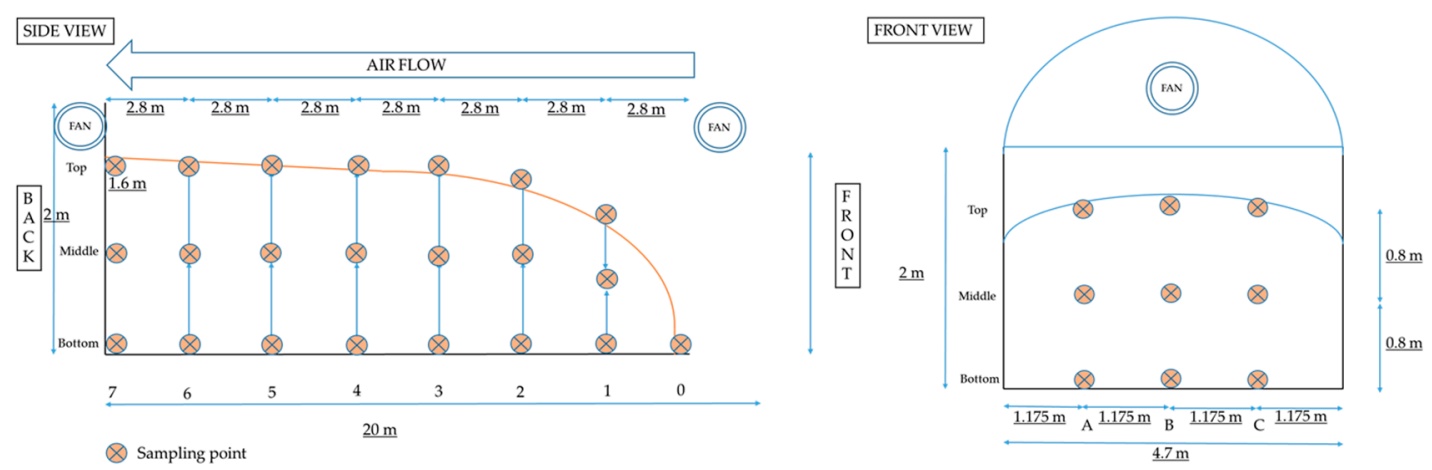

Figure 2. Side and front view of the composting facility. 
Temperature data from both the cattle barn and composting facility were collected using temperature logger data (HOBO ${ }^{\circledR}$ Pro v2 Temperature/Relative Humidity Data Logger, Onset, MA, USA), placed inside the chamber and from the Korean Meteorological Data Open Portal (www.data.kma.go.kr), respectively.

\subsection{Sampling Procedure}

The first and last samples from the dynamic chamber were taken on 2 November 2018, and 1 November 2019, accordingly. The samples were taken twice during the week, usually on Tuesday and Friday. On the sampling day, the gas samples were collected three times with triplicates between 9:00 to 15:00 (by $3 \mathrm{~h}$ interval). The first sample was taken one hour later of closing the chamber and turning on the fan. The air sample from the inlet and outlet chambers were taken using a $25 \mathrm{~mL}$ syringe (Jung Rim Syringe, Jung Rim Medical Industrial Co. Ltd., Seoul, Korea) through a plastic hose (outer diameter $=0.6 \mathrm{~mm}$ and inner diameter $=0.4 \mathrm{~mm}$ ) connected to a pump (Oil-less Diaphragm Pump 35DNS, G\&M Tech Inc., Yongin, Korea). The collected samples were stored in $8 \mathrm{~mL}$ vacuumed glass-vials (LK LAB KOREA 99429, LK Lab Korea, Namyangju, Korea) and sealed with butyl-rubber septa (Samwoo Kurex ${ }^{\circledR} 15$ mm, Samwoo Kurex, Seoul, Korea). The glass vials were vacuumed using a vacuum machine (VALUE ${ }^{\circledR}$ TF-VE245N, Teddington-France, Villeneuve la Garenne, France) for $5 \mathrm{~min}$ [23]. After collection, the glass vials were properly sealed with parafilm and stored for further gas chromatography (GC) analysis (Figure 3).
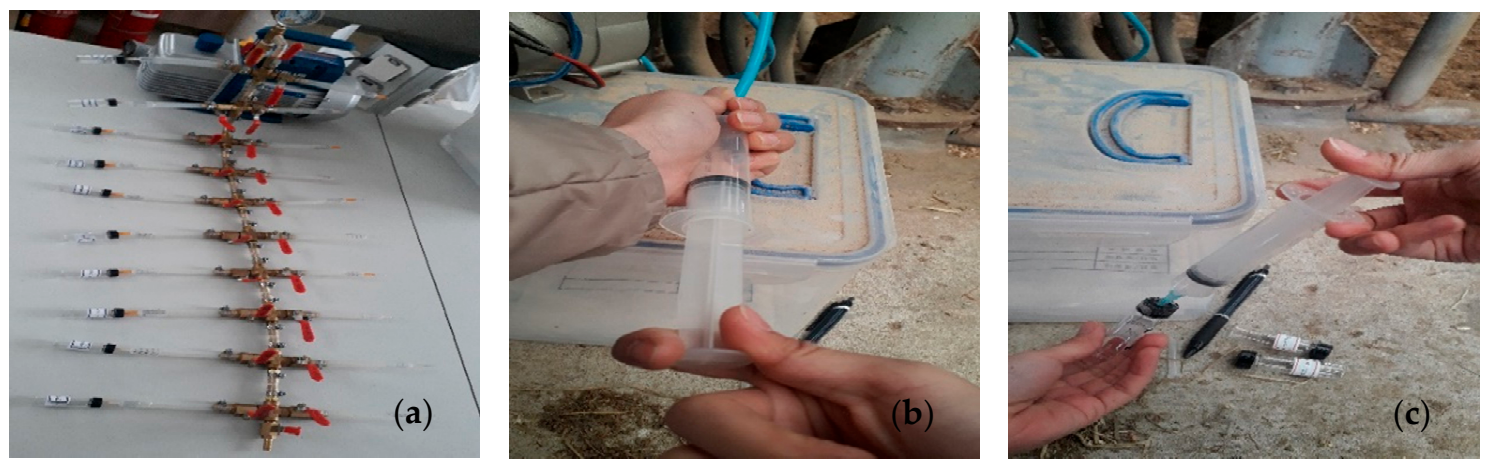

Figure 3. Gas sampling procedure: (a) vacuuming the glass vial, (b) taking gas sample using the syringe, (c) transferring gas sample to vacuumed glass vial.

\subsection{Flow Rate Measurement}

To calculate the air flow rate through the chamber, the wind speed profile of the fan drawing air into the chamber was determined using an airflow capture hood or balometer (Alnor ${ }^{\circledR}$ Electronic Balancing Tool EBT721, TSI Incorporated, Shoreview, MN, USA and AIRFLOW ${ }^{\mathrm{TM}}$ Instrument ProHood $^{\mathrm{TM}}$ Capture Hood PH721, TSI Instruments Ltd., London, UK). The wind speed was recorded across the surface area of the fan giving a flow rate of $0.848 \mathrm{~m}^{3} / \mathrm{s}$.

\subsection{Gas Chromatography Analysis}

To investigate the sources and emissions of major GHG $\left(\mathrm{N}_{2} \mathrm{O}, \mathrm{CH}_{4}\right)$, accurate concentration analysis was made after sample collection. Gas concentration analysis was performed using a gas chromatograph device to simultaneously analyze $\mathrm{N}_{2} \mathrm{O}$ and $\mathrm{CH}_{4}$. An electronic capture detector and a pulsed discharge detector (PDD) (VICI PDDs, Valco Instrument Co. Inc., Houston, TX, USA) were equipped in gas chromatography (iGC7200A, DS Science, Gwangju, Korea). For gas analysis, Carboxen 1000 (80/100 mesh, $1.2 \mathrm{~m} \times 1 / 8$ inch) column was used and helium gas with $99.999 \%$ purity was introduced as a carrier. Temperature set-up of injector, column, and oven were 50,160 , and $50{ }^{\circ} \mathrm{C}$, respectively. The concentrations of $\mathrm{N}_{2} \mathrm{O}$ and $\mathrm{CH}_{4}$ standard gas used in this study were $1 \mathrm{ppm}$ and 100 ppm, respectively. Before analysis of the samples, GC calibration was carried out to investigate the 
precision and reproducibility of the repetition during analysis and each standard gas was analyzed 20 times.

\subsection{Calculation of Emission Fluxes}

The samples $(1 \mathrm{~mL}$ ) were taken from the $8 \mathrm{~mL}$ glass-vials using a $1 \mathrm{~mL}$ SGE syringe (Trajan Scientific Australia Pty Ltd., Victoria, Australia) to calculate emission fluxes of $\mathrm{CH}_{4}$ and $\mathrm{N}_{2} \mathrm{O}$. Each sample was injected three times to obtain $\mathrm{N}_{2} \mathrm{O}$ and $\mathrm{CH}_{4}$ average concentration. $\mathrm{N}_{2} \mathrm{O}$ and $\mathrm{CH}_{4}$ fluxes were calculated using the following equations,

$$
\text { Flux }=\mathrm{FR} \times \Delta \mathrm{C} / \mathrm{A}
$$

where FR represents the air flow rate through the chamber $\left(\mathrm{m}^{3} / \mathrm{s}\right)$, A is the surface area of emitting materials in the chamber $\left(\mathrm{m}^{2}\right)$, and $\Delta C$ indicates the difference in gas densities in the air inlet and outlet of the chamber $\left(\mathrm{mg} / \mathrm{m}^{3}\right)$.

$$
\Delta \mathrm{C}=\left(\mathrm{C}_{\text {out }}-\mathrm{C}_{\text {in }}\right)_{\mathrm{TGA}} \times \mathrm{P} \times \mathrm{M} / \mathrm{T} \times \mathrm{R}
$$

where $\left(\mathrm{C}_{\text {out }}-\mathrm{C}_{\text {in }}\right)_{\text {TGA }}$ is the difference in concentration measured using gas chromatography (ppm), $p$ represents the atmospheric pressure $(\mathrm{Pa}), \mathrm{M}$ indicates the molecular weight of methane or nitrous oxide $\left(\mathrm{CH}_{4}=16.04(\mathrm{~g} / \mathrm{mol}) ; \mathrm{N}_{2} \mathrm{O}=44.01(\mathrm{~g} / \mathrm{mol})\right)$, $\mathrm{T}$ is the average temperature of the analyzed air $(\mathrm{K})$, and $\mathrm{R}$ shows the universal gas constant $(8.314 \mathrm{~J} / \mathrm{mol} \mathrm{K})$.

To calculate the emission fluxes from litter in the barn, fluxes were measured after removing the litter from the cattle barn and later subtracted from the emission fluxes. In addition, while converting the annual GHG emissions from the Hanwoo cattle manure management systems to $\mathrm{CO}_{2}$ equivalent, global warming potential values for the 100-year time horizon mentioned in the IPCC Fourth Assessment Report were considered [24].

\subsection{Statistical Analysis}

The graphs were prepared using Sigma plot (version 10, 2007) and statistical analysis was conducted using GraphPad Prism (version 8.4.2, 2020). Data obtained from the cattle barn and composting facility were analyzed with one-way analysis of variance (ANOVA). Multiple comparisons were performed using Tukey's honest significant difference (HSD) post hoc test. A $p$-value of $<0.05$ was designated to determine statistical significance.

\section{Results and Discussion}

\subsection{Greenhouse Gas Emissions from Litter in the Hanwoo Cattle Barn}

\subsubsection{Estimation of Methane Flux}

Figure 4 shows the variation in average $\mathrm{CH}_{4}$ flux from the litter on the sampling days. The monthly average of $\mathrm{CH}_{4}$ flux was varied from 0.0 to $30.0 \pm 13.7 \mu \mathrm{g} / \mathrm{m}^{2} \mathrm{~s}$ during the whole measurement period (November 2018 to October 2019).

The $\mathrm{CH}_{4}$ flux in October $\left(29.997 \pm 13.692 \mu \mathrm{g} / \mathrm{m}^{2} \mathrm{~s}\right)$ were higher over the values in the other months, while very low flux was recorded in June (Figure 4). Generally, the $\mathrm{CH}_{4}$ flux is influenced by temperature which affects microbial activity; i.e., higher $\mathrm{CH}_{4}$ emission with high temperature $[25,26]$. Studies on litter reported that temperature ranges from of 35 to $50{ }^{\circ} \mathrm{C}$ was the best for microbial activity, which can be achieved with a litter height of 20 to $30 \mathrm{~cm}[27,28]$. In this study, the shallow height of the litter $\left(10 \mathrm{~cm}\right.$ ) and relatively low air temperature (below $35^{\circ} \mathrm{C}$ ) resulted in low $\mathrm{CH}_{4}$ flux during the summer (Figure 4). Moreover, low $\mathrm{CH}_{4}$ flux may also be caused by events such as litter mixing (red boxes) and change of bedding materials (green and blue boxes) since such events facilitate air-supply to the litter mixture. Another possible reason for low $\mathrm{CH}_{4}$ emission during the summer 
could be the low moisture content (approximately 12.9\%) of the bedding material after replacing the litter and it requires some time to reach the optimal moisture level for $\mathrm{CH}_{4}$ production as moisture content can influence microbial activity [29]. Furthermore, compaction of the litter by cattle hoofs may prevent increasing the temperature of litter and ultimately results in low $\mathrm{CH}_{4}$ emission [30]. $\mathrm{CH}_{4}$ flux from the livestock manure also depends on the amount of manure produced and the part of amount anaerobically decomposes [31]. After replacing the litter (green box in March), $\mathrm{CH}_{4}$ flux was almost close to zero and then the flux was detected again in the middle of July. Furthermore, following litter mixing, the $\mathrm{CH}_{4}$ flux down temporarily for a few days and the emission was abruptly increased around $9.534 \pm 11.823 \mu \mathrm{g} / \mathrm{m}^{2} \mathrm{~s}$ in August with some fluctuations. Such phenomena might be happened due to the microbial degradation of organic materials for the last three months, which affects the $\mathrm{CH}_{4}$ flux through the acidification of organic materials [32,33].

Time-specific $\mathrm{CH}_{4}$ flux in a day was tended to be higher at 09:00 $\left(7.107 \pm 13.526 \mu \mathrm{g} / \mathrm{m}^{2} \mathrm{~s}\right)$ and showed comparatively lower fluxes at 12:00 and 15:00 (5.408 \pm 10.019 and 5.840 $\pm 10.801 \mu \mathrm{g} / \mathrm{m}^{2} \mathrm{~s}$, respectively) (Figure 5a). However, daily variation of $\mathrm{CH}_{4}$ flux did not show significant difference with each other as the time changes $(p>0.05)$. On the other hand, the average $\mathrm{CH}_{4}$ flux during the fall $\left(18.538 \pm 14.841 \mu \mathrm{g} / \mathrm{m}^{2} \mathrm{~s}\right)$ found to be significantly higher than other seasonal fluxes $(p<0.05)$, while the spring season had the lowest average $\mathrm{CH}_{4}$ flux (Figure 5b).

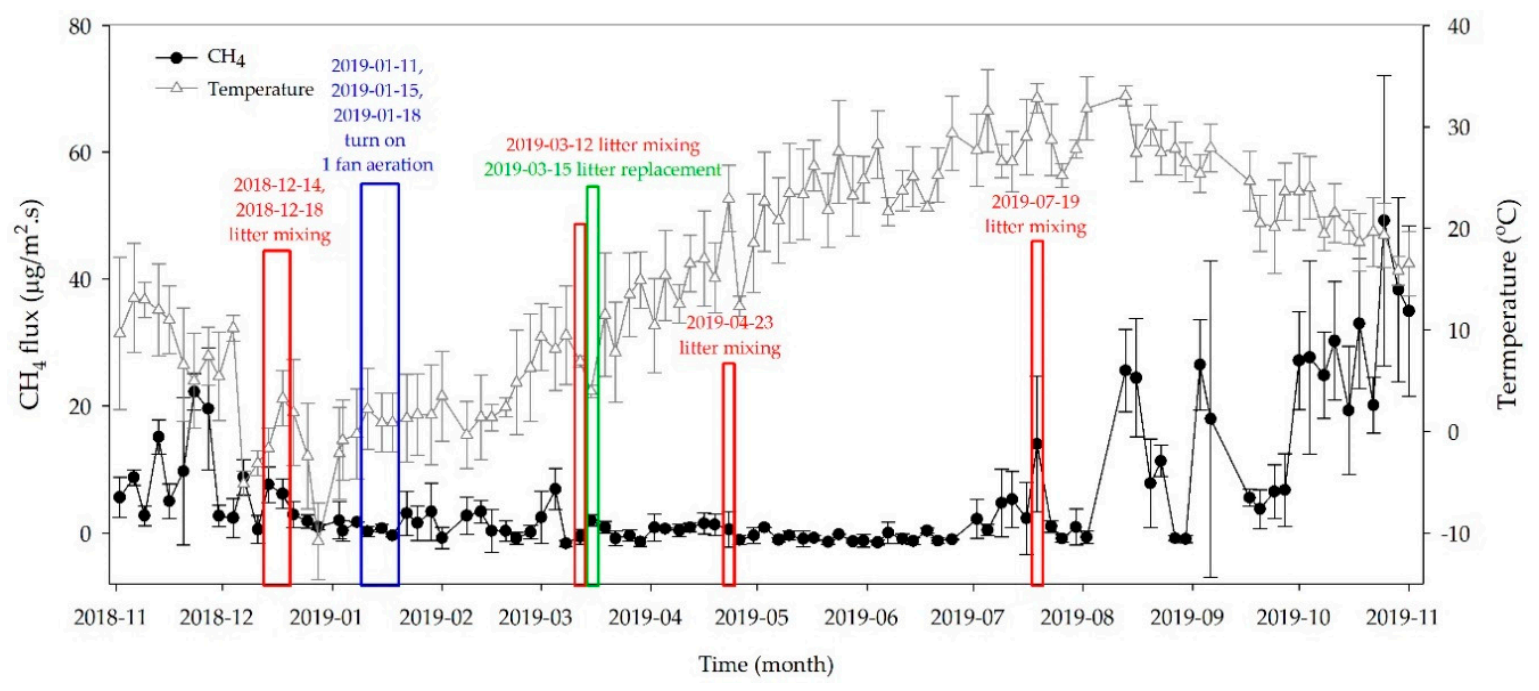

Figure 4. Variation in average $\mathrm{CH}_{4}$ flux from litter on the day of sampling during the study (error bars represent the standard deviation of the average).
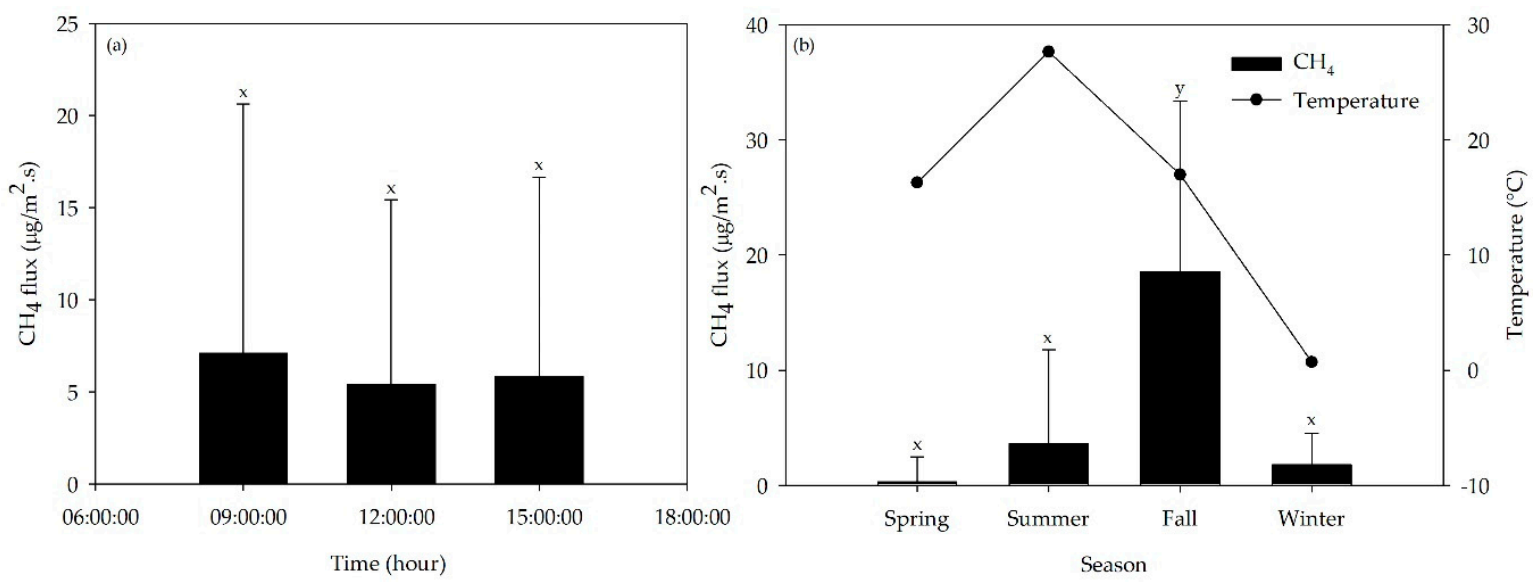

Figure 5. Average $\mathrm{CH}_{4}$ flux from litter by (a) time and (b) season (error bars represent the standard deviation of the average). Flux means with the same letter are not significantly different $(p>0.05)$. 


\subsubsection{Estimation of Nitrous Oxide Flux}

The variation in average $\mathrm{N}_{2} \mathrm{O}$ flux from litter in the barn on the sampling days are elucidated in Figure 6. The monthly average of $\mathrm{N}_{2} \mathrm{O}$ flux was ranged from $0.896 \pm 0.557$ to $2.925 \pm 2.853 \mu \mathrm{g} / \mathrm{m}^{2} \mathrm{~s}$ during the whole measurement period (November 2018 to October 2019).

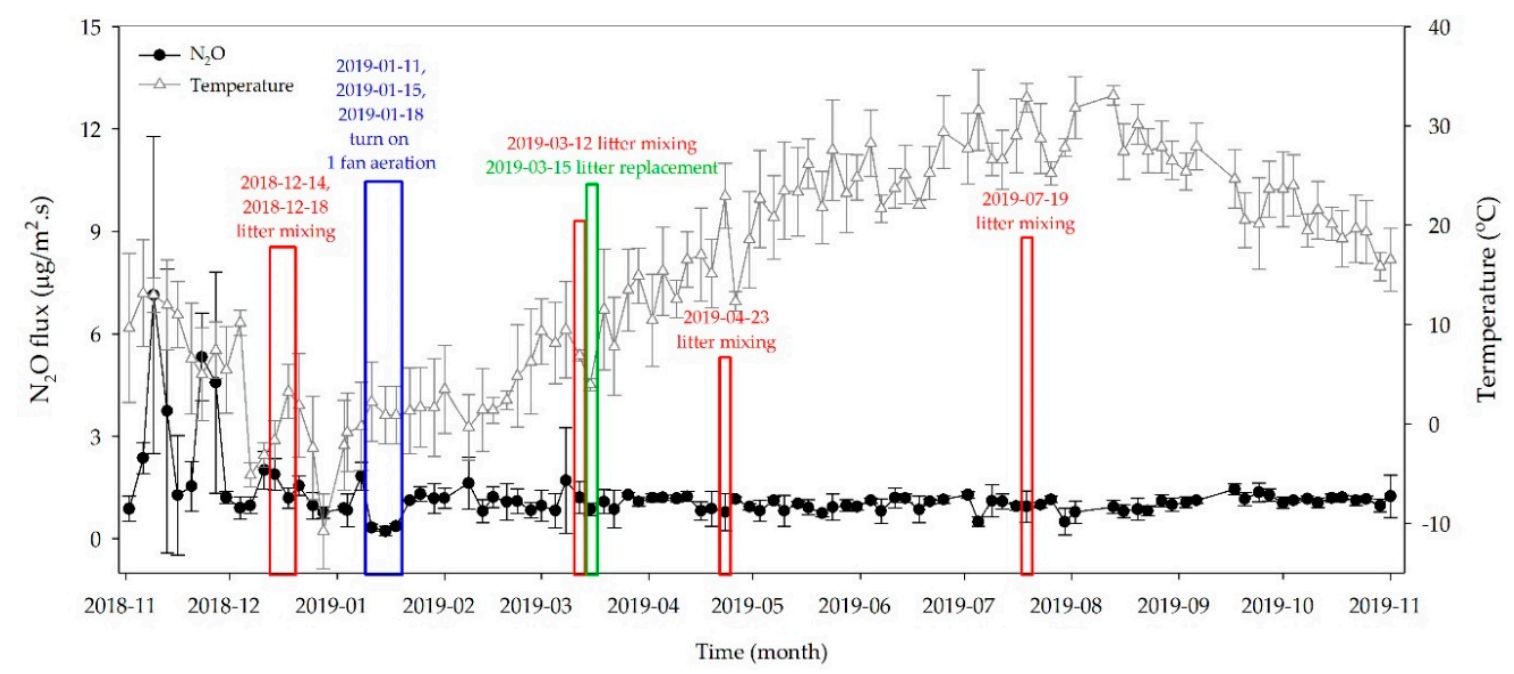

Figure 6. Variation in average $\mathrm{N}_{2} \mathrm{O}$ flux from litter on the day of sampling during the study (error bars represent the standard deviation of the average).

$\mathrm{N}_{2} \mathrm{O}$ is well known as one of GHGs having high global warming potential with only a small amount. The highest average $\mathrm{N}_{2} \mathrm{O}$ flux was estimated in November as $2.925 \pm 2.853 \mu \mathrm{g} / \mathrm{m}^{2} \mathrm{~s}$, while the lowest was in January as $0.896 \pm 0.557 \mu \mathrm{g} / \mathrm{m}^{2} \mathrm{~s}$, respectively. However, the fluctuation of $\mathrm{N}_{2} \mathrm{O}$ flux was not very different as compared to $\mathrm{CH}_{4}$. The time-specific $\mathrm{N}_{2} \mathrm{O}$ flux showed the highest level of $1.263 \pm 0.948 \mu \mathrm{g} / \mathrm{m}^{2} \mathrm{~s}$ at 12:00 but the fluxes in the morning at 09:00 and in the afternoon at 15:00 were slightly low with $1.249 \pm 1.072$ and $1.211 \pm 1.353 \mu \mathrm{g} / \mathrm{m}^{2} \mathrm{~s}$, respectively (Figure 7a). However, no significant difference in time-specific $\mathrm{N}_{2} \mathrm{O}$ flux was observed during the study period $(p>0.05)$.
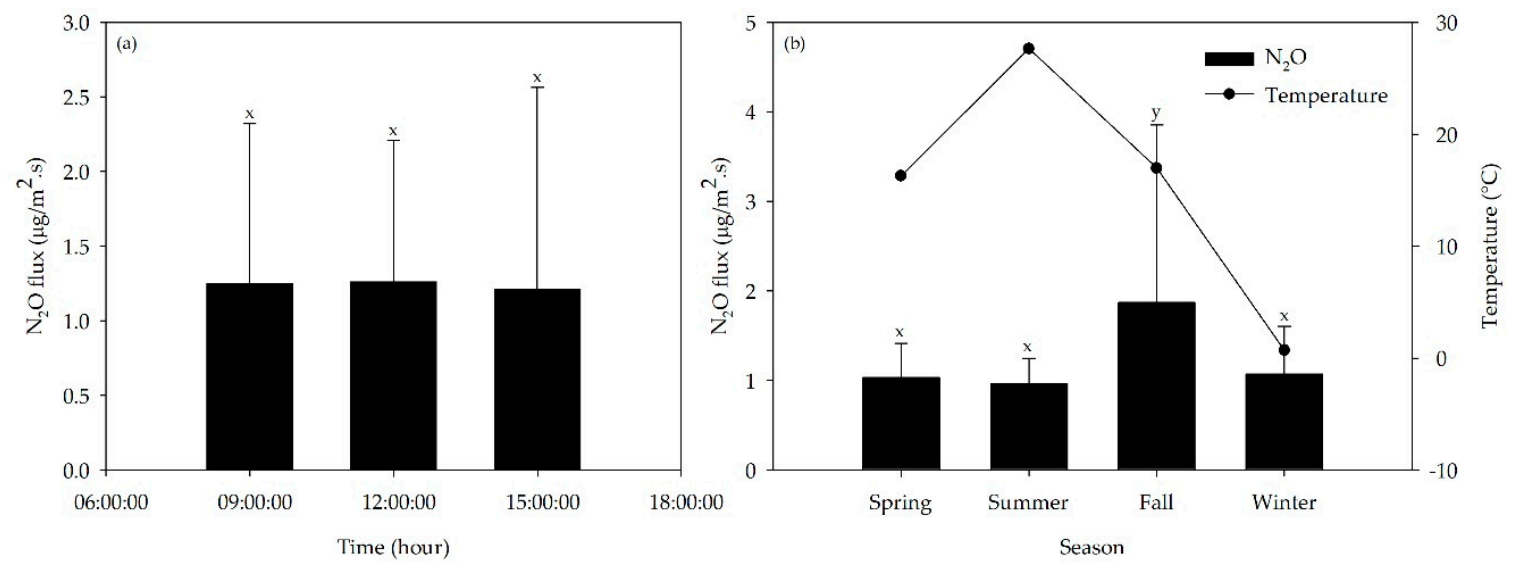

Figure 7. Average $\mathrm{N}_{2} \mathrm{O}$ flux from litter by (a) time and (b) season (error bars represent the standard deviation of the average). Flux means with the same letter are not significantly different $(p>0.05)$.

The seasonal variation of $\mathrm{N}_{2} \mathrm{O}$ flux follows delineates similar trend as that of $\mathrm{CH}_{4}$ flux (Figure $7 \mathrm{~b}$ ). The average $\mathrm{N}_{2} \mathrm{O}$ flux $\left(1.870 \pm 1.990 \mu \mathrm{g} / \mathrm{m}^{2} \mathrm{~s}\right)$ during the fall season was significantly higher than the other seasonal fluxes $(p<0.05)$, which indicated that the litter management practices played an important role in $\mathrm{N}_{2} \mathrm{O}$ emission rather than the temperature. Both aerobic and anaerobic status favor $\mathrm{N}_{2} \mathrm{O}$ emission from livestock manure with bedding materials [31]. When organic nitrogen and 
ammonia nitrogen in urine is oxidized into hydroxylamine or nitrite under aerobic conditions, part of the $\mathrm{N}_{2} \mathrm{O}$ gas can be produced $[34,35]$ or further $\mathrm{N}_{2} \mathrm{O}$ emission occurs when the oxidized form, nitrate, is reduced under anoxic condition by denitrifier [36]. According to the litter status, simultaneous nitrification and denitrification (SND) may occur under aerobic conditions, whereas events such as litter mixing and change of bedding materials shows influence on GHG emission rather than other environmental conditions.

\subsection{Greenhouse Gas Emissions from Composting Lot}

The livestock production and manure management systems in Korea are very different to those of other parts of the world due to regional climate and limited land resources. For example, a pasture-based livestock farm will possibly focus on land spreading for manure management, whereas in barn-based farming system manure cannot be spread in the soil directly, rather the entire manure and bedding is transferred to the composting facility. Composting is done as a manure management strategy to minimize the impact of land spread manure to the environment. The Korean government recommends that prior to land application, cattle manure should stay in the composting lot for over 6 months. Accordingly, the GHG emission from composting lot need to be estimated after measuring from the cattle barn.

Composting in general is an aerobic process. Gas emission under anaerobic condition would therefore be easily to be ignored. However, since manure contains $9-30 \%$ solids and $70-91 \%$ moisture, the inner space of solid fractions may form anaerobic conditions and favor $\mathrm{CH}_{4}$ and $\mathrm{N}_{2} \mathrm{O}$ production [37]. In addition, during composting if processes such as turning the composting pile and aeration not performed properly, the GHG emissions increase further [38,39].

Most cattle farms in Korea concentrate on livestock productivity without much consideration of the environmental issues related to manure management. Hence, to reflect the actual farm practices, in this study activities like turning the composting pile or aeration was not performed during composting. The measurement was carried out right after collecting the mixture of manure and bedding materials from the cattle barn to exchange the litter. The variation in average $\mathrm{CH}_{4}$ and $\mathrm{N}_{2} \mathrm{O}$ fluxes on the sampling days are shown in Figure 8.

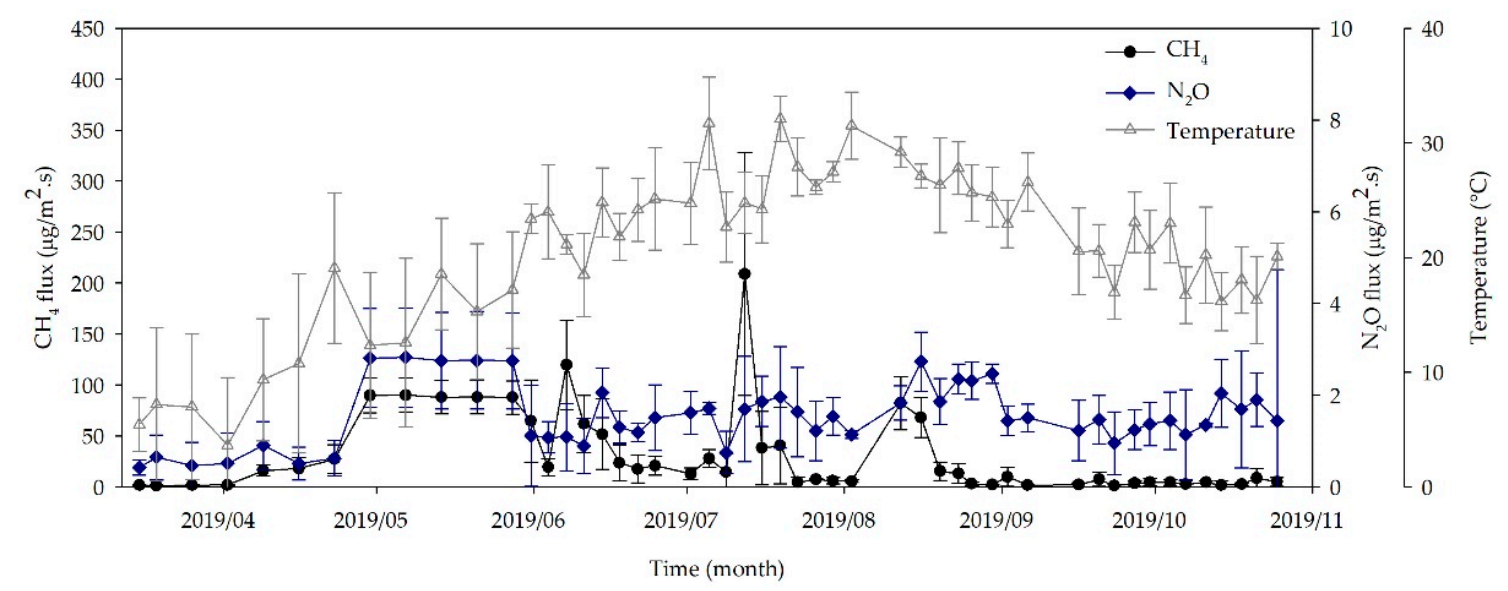

Figure 8. Variation in average $\mathrm{CH}_{4}$ and $\mathrm{N}_{2} \mathrm{O}$ fluxes from manure composting lot on the day of sampling during the study (error bars represent the standard deviation of the average).

The monthly averages of $\mathrm{CH}_{4}$ and $\mathrm{N}_{2} \mathrm{O}$ fluxes ranged from $1.449 \pm 0.783$ to $86.930 \pm 19.092$ and $0.511 \pm 0.410$ to $2.629 \pm 1.105 \mu \mathrm{g} / \mathrm{m}^{2}$ s during the composting period. A different trend in $\mathrm{CH}_{4}$ emission was observed when compared to the emission from litter in the cattle barn with respect to temperature (Figure 9a). During the spring season, $\mathrm{CH}_{4}$ emission was abruptly increased till May along with gradual increment of temperature, of which emission was caused by microbial activity and showed significant difference with other monthly average fluxes $(p<0.05)$. For $\mathrm{N}_{2} \mathrm{O}$, significantly higher emission was 
also observed in May compared to the other months $(p<0.05)$ (Figure $9 b)$. Gilroyed et al. explained the detail biological mechanisms of GHG production during the composting process [40]. They showed a typical GHG emission pattern over time with respect to microbial activity, temperature profile, and oxygen $\left(\mathrm{O}_{2}\right)$ concentration. High $\mathrm{CH}_{4}$ emission was observed at the beginning of composting under thermophilic temperature, while $\mathrm{N}_{2} \mathrm{O}$ emission profile showed the opposite trend with $\mathrm{CH}_{4}$. This finding is in line with the results reported by Hao et al. [41]. Rapid consumption of $\mathrm{O}_{2}$ during composting due to microbial degradation of organic compounds results in a thermophilic condition, which produces $\mathrm{CH}_{4}$ via methanogenesis [42]. $\mathrm{N}_{2} \mathrm{O}$ can be emitted from the composting pile through both nitrification and denitrification processes [43,44]. In this study, the actual composting process performed in the Korean farms were considered, therefore, the majority of the $\mathrm{N}_{2} \mathrm{O}$ was emitted during composting through nitrification. As the time passes, the temperature of the composting pile reaches to mesophilic levels, and ultimately enables the growth of nitrifying bacteria which are responsible for $\mathrm{N}_{2} \mathrm{O}$ emission.
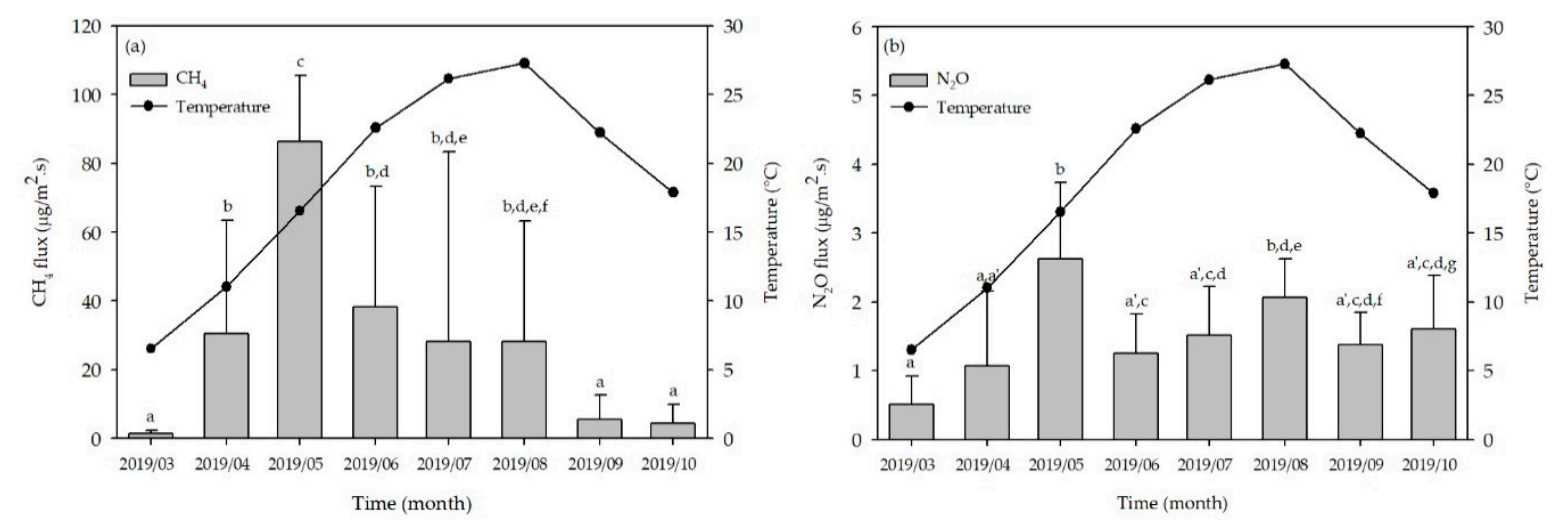

Figure 9. Monthly average emissions of (a) $\mathrm{CH}_{4}$ and (b) $\mathrm{N}_{2} \mathrm{O}$ from composting lot. Flux means with the same letter are not significantly different $(p>0.05)$.

\subsection{Greenhouse Gas Emissions from Manure Management Systems}

By contrast with other countries, cattle in Korea are mostly raised in the barn due to lack of pasture. The annual emissions of $\mathrm{CH}_{4}$ and $\mathrm{N}_{2} \mathrm{O}$ fluxes from litter in the barn were 6.192 and $1.242 \mu \mathrm{g} / \mathrm{m}^{2}$ $\mathrm{s}$, respectively, from 46 animals in $736 \mathrm{~m}^{2}$ of cattle barn $\left(3.124\right.$ and $0.627 \mathrm{~kg} \mathrm{CH}_{4}$ and $\mathrm{N}_{2} \mathrm{O}$ /animal year, respectively). Furthermore, $\mathrm{CH}_{4}$ and $\mathrm{N}_{2} \mathrm{O}$ fluxes from litter based on unit animal were 78.1 and $184.2 \mathrm{~kg} \mathrm{CO}$ eq/animal year, respectively when converted to $\mathrm{CO}_{2}$ equivalent. On the other hand, the average $\mathrm{CH}_{4}$ and $\mathrm{N}_{2} \mathrm{O}$ fluxes from the composting lot were $28.037 \pm 39.848$ and $1.514 \pm 1.051 \mu \mathrm{g} / \mathrm{m}^{2}$ $\mathrm{s}$, respectively (2.235 and $0.098 \mathrm{~kg} \mathrm{CH}_{4}$ and $\mathrm{N}_{2} \mathrm{O}$ /animal year, respectively). After converting to $\mathrm{CO}_{2}$ equivalent, $\mathrm{CH}_{4}$ and $\mathrm{N}_{2} \mathrm{O}$ fluxes from composting lot based on unit animal were calculated as 55.9 and $28.9 \mathrm{~kg} \mathrm{CO}_{2} \mathrm{eq} /$ animal year, respectively. Therefore, in total a GHG of $347.1 \mathrm{~kg} \mathrm{CO} 2 \mathrm{eq} /$ animal year was emitted from the Hanwoo cattle manure management systems.

\subsection{Comparison of Greenhouse Gas Emissions with Intergovernmental Panel on Climate Change (IPCC) Guidelines}

According to 2006 IPCC GL for National Greenhouse Gas Inventories [23], the Tier 1 values of manure management $\mathrm{CH}_{4}$ emission factor for beef cattle in Asia, North America, Western Europe, and South America are 1, 1, 8, and $1 \mathrm{~kg} \mathrm{CH}_{4}$ /animal year, respectively. While for $\mathrm{N}_{2} \mathrm{O}$, the value is $0.342 \mathrm{~kg} \mathrm{~N}_{2} \mathrm{O}$ /animal year, with consideration of the manure treatment facilities including liquid treatment $(2.5 \%)$, solid storage $(90.7 \%)$, and miscellaneous $(6.8 \%)$. In this study, annual emissions of $\mathrm{CH}_{4}$ and $\mathrm{N}_{2} \mathrm{O}$ emission from the Hanwoo cattle manure management systems were almost 5.4 and 2.1 times, respectively higher than the values provided by IPCC. Jo et al. reported that such variation might be attributed to the differences in feeding systems and cattle breeds as the values mentioned 
by IPCC values were estimated based on the studies conducted mainly in western countries [21]. Country-specific emission factors are, therefore, needed rather than using the values of the 2006 IPCC GL to develop effective and efficient GHG emission reduction strategies for the livestock industries.

\section{Conclusions}

This study was conducted to evaluate the GHG emission flux from Hanwoo cattle manure management systems using the dynamic chamber method. $\mathrm{CH}_{4}$ and $\mathrm{N}_{2} \mathrm{O}$ emission fluxes from litter in the cattle barn and composting lot were monitored and estimated. The monthly average $\mathrm{CH}_{4}$ and $\mathrm{N}_{2} \mathrm{O}$ emission fluxes from litter in the barn during the experimental period varied from 0.0 to $30.0 \pm 13.7 \mu \mathrm{g} / \mathrm{m}^{2} \mathrm{~s}$ and $0.896 \pm 0.557$ to $2.925 \pm 2.853 \mu \mathrm{g} / \mathrm{m}^{2} \mathrm{~s}$, respectively. The annual emissions of $\mathrm{CH}_{4}$ and $\mathrm{N}_{2} \mathrm{O}$ fluxes from litter were estimated as 6.192 and $1.242 \mu \mathrm{g} / \mathrm{m}^{2} \mathrm{~s}$, respectively $(3.124$ and $0.627 \mathrm{~kg} \mathrm{CH}_{4}$ and $\mathrm{N}_{2} \mathrm{O}$ /animal year, respectively). The monthly averages of $\mathrm{CH}_{4}$ and $\mathrm{N}_{2} \mathrm{O}$ fluxes ranged from $1.449 \pm 0.783$ to $86.930 \pm 19.092$ and $0.511 \pm 0.410$ to $2.629 \pm 1.105 \mu \mathrm{g} / \mathrm{m}^{2} \mathrm{~s}$ during the composting period and the calculated annual $\mathrm{CH}_{4}$ and $\mathrm{N}_{2} \mathrm{O}$ emissions from the composting lot were 2.235 and $0.098 \mathrm{~kg} \mathrm{CH}_{4}$ and $\mathrm{N}_{2} \mathrm{O}$ /animal year, respectively. A comparison with the values for different continents in the world mentioned in 2006 IPCC GL for National Greenhouse Gas Inventories revealed that $\mathrm{CH}_{4}$ and $\mathrm{N}_{2} \mathrm{O}$ emissions from the Hanwoo cattle manure management systems were much higher than those reported. Hence, the results of this study highlight the significance and need to have country-specific emission factors as well as to encourage further studies to develop efficient and effective GHG reduction strategies for the livestock sector in Korea.

Author Contributions: Conceptualization, S.W., C.R. and K.-H.P; methodology, S.W. and K.-H.P; formal analysis, Y.Y., S.S., S.K. and E.N.; investigation, Y.Y., S.S., S.K. and E.N.; resources, K.-H.P.; data curation, S.W., Y.Y., A.R. and E.N.; writing—original draft preparation, M.M.A.H. and A.R.; writing-review and editing, A.R., S.W., C.R. and K.-H.P.; supervision, S.W. and K.-H.P.; project administration, K.-H.P.; funding acquisition, K.-H.P. All authors have read and agreed to the published version of the manuscript.

Funding: This research was funded by Rural Development Administration of Korea, grant number PJ01359002.

Conflicts of Interest: The authors declare no conflict of interest. The funders had no role in the design of the study; in the collection, analyses, or interpretation of data; in the writing of the manuscript; or in the decision to publish the results.

\section{References}

1. Steinfeld, H.; Gerber, P.; Wassenaar, T.D.; Castel, V.; Rosales, M.; Rosales, M.; de Haan, C. Livestock's Long Shadow: Environmental Issues and Options; Food \& Agriculture Organization: Rome, Italy, 2006.

2. O'Mara, F. The significance of livestock as a contributor to global greenhouse gas emissions today and in the near future. Anim. Feed. Sci. Technol. 2011, 166, 7-15. [CrossRef]

3. Denmead, O.T. Approaches to measuring fluxes of methane and nitrous oxide between landscapes and the atmosphere. Plant Soil 2008, 309, 5-24. [CrossRef]

4. US EPA. Understanding Global Warming Potentials. Available online: https://www.epa.gov/ghgemissions/ understanding-global-warming-potentials (accessed on 28 May 2020).

5. $\quad$ Liang, Y.; Xin, H.; Wheeler, E.F.; Gates, R.S.; Li, H.; Zajaczkowski, J.S.; Topper, P.A.; Casey, K.; Behrends, B.R.; Burnham, D.J.; et al. Ammonia emissions from U.S. Laying hen houses in Iowa and Pennsylvania. Trans. ASAE 2005, 48, 1927-1941. [CrossRef]

6. Cortus, E.; Jacobson, L.D.; Hetchler, B.P.; Heber, A.J.; Bogan, B.W. Methane and nitrous oxide analyzer comparison and emissions from dairy freestall barns with manure flushing and scraping. Atmos. Environ. 2015, 100, 57-65. [CrossRef]

7. Peters, E.B.; McFadden, J.P. Continuous measurements of net $\mathrm{CO}_{2}$ exchange by vegetation and soils in a suburban landscape. J. Geophys. Res. Space Phys. 2012, 117, 1-16. [CrossRef]

8. Butterbach-Bahl, K.; Sander, B.O.; Pelster, D.; Díaz-Pinés, E. Quantifying greenhouse gas emissions from managed and natural soils. In Methods for Measuring Greenhouse Gas Balances and Evaluating Mitigation Options in Smallholder Agriculture; Springer: Cham, Switzerland, 2016; pp. 71-96. 
9. Rochette, P.; Eriksen-Hamel, N.S. Chamber Measurements of Soil Nitrous Oxide Flux: Are Absolute Values Reliable? Soil Sci. Soc. Am. J. 2008, 72, 331-342. [CrossRef]

10. Pavelka, M.; Acosta, M.; Kiese, R.; Altimir, N.; Brümmer, C.; Crill, P.; Darenova, E.; Fuß, R.; Gielen, B.; Graf, A.; et al. Standardisation of chamber technique for $\mathrm{CO}_{2}, \mathrm{~N} 2 \mathrm{O}$ and $\mathrm{CH}_{4}$ fluxes measurements from terrestrial ecosystems. Int. Agrophys. 2018, 32, 569-587. [CrossRef]

11. Bouwman, A.F.; Boumans, L.J.M.; Batjes, N. Modeling global annual $\mathrm{N}_{2} \mathrm{O}$ and $\mathrm{NO}$ emissions from fertilized fields. Glob. Biogeochem. Cycles 2002, 16, 28-1-28-9. [CrossRef]

12. Jørgensen, C.J.; Struwe, S.; Elberling, B. Temporal trends in N2O flux dynamics in a Danish wetland-Effects of plant-mediated gas transport of $\mathrm{N}_{2} \mathrm{O}$ and $\mathrm{O}_{2}$ following changes in water level and soil mineral-N availability. Glob. Chang. Boil. 2011, 18, 210-222. [CrossRef]

13. Lapitan, R.; Wanninkhof, R.; Mosier, A. Methods for stable gas flux determination in aquatic and terrestrial systems. In Developments in Atmospheric Science; Elsevier BV: Amsterdam, The Netherlands, 1999; pp. 29-66.

14. Breuninger, C.; Oswald, R.; Kesselmeier, J.; Meixner, F.X. The dynamic chamber method: Trace gas exchange fluxes (NO, NO2, O3) between plants and the atmosphere in the laboratory and in the field. Atmos. Meas. Tech. 2012, 5, 955-989. [CrossRef]

15. Ministry of Knowledge Economy. 3rd National Greenhouse Gas Inventory Meeting; Ministry of Knowledge Economy: Gyeonggi, Korea, 2009.

16. Greenhouse Gas Inventory \& Research Center of Korea. National Greenhouse Inventory Report of Korea, Annuls; Greenhouse Gas Inventory \& Research Center of Korea: Seoul, Korea, 2015.

17. Park, K.-H.; Jeon, J.; Jeon, K.; Kwag, J.; Choi, D. Low greenhouse gas emissions during composting of solid swine manure. Anim. Feed. Sci. Technol. 2011, 166, 550-556. [CrossRef]

18. Ji, E.S.; Park, K.-H. Methane and Nitrous Oxide Emissions from Livestock Agriculture in 16 Local Administrative Districts of Korea. Asian-Australas. J. Anim. Sci. 2012, 25, 1768-1774. [CrossRef] [PubMed]

19. Ha, S.; Tae, S.; Kim, R. A Study on the Limitations of Korea's National Roadmap for Greenhouse Gas Reduction by 2030 and Suggestions for Improvement. Sustainability 2019, 11, 3969. [CrossRef]

20. Korean Statistical Service Information (KOSIS). Livestock Trend Survey in the Fourth Quarter of 2020; KOSIS: Daejon, Korea, 2019.

21. Jo, N.; Kim, J.; Seo, S.-W. Comparison of models for estimating methane emission factor for enteric fermentation of growing-finishing Hanwoo steers. SpringerPlus 2016, 5, 1212. [CrossRef] [PubMed]

22. Febrisiantosa, A.; Lee, J.; Choi, H. Greenhouse gas emissions from cattle production sector in Korea. Indones. J. Anim. Vet. Sci. 2016, 21, 112. [CrossRef]

23. Rochette, P.; Bertrand, N. Soil air sample storage and handling using polypropylene syringes and glass vials. Can. J. Soil Sci. 2003, 83, 631-637. [CrossRef]

24. Forster, P.; Ramaswamy, V.; Artaxo, P.; Berntsen, T.; Betts, R.; Fahey, D.W.; Haywood, J.; Lean, J.; Lowe, D.C.; Myhre, G.; et al. Changes in Atmospheric Constituents and in Radiative Forcing. In Climate Change 2007: The Physical Science Basis, Contribution of Working Group I to the Fourth Assessment Report of the Intergovernmental Panel on Climate Change; Solomon, S., Qin, D., Manning, M., Chen, Z., Marquis, M., Averyt, K.B., Tignor, M., Miller, H.L., Eds.; Cambridge University Press: Cambridge, UK, 2007; pp. 129-234.

25. Wang, J.; Duan, C.; Ji, Y.; Sun, Y. Methane emissions during storage of different treatments from cattle manure in Tianjin. J. Environ. Sci. 2010, 22, 1564-1569. [CrossRef]

26. Grossi, G.; Goglio, P.; Vitali, A.; Williams, A. Livestock and climate change: Impact of livestock on climate and mitigation strategies. Anim. Front. 2018, 9, 69-76. [CrossRef]

27. McKinley, V.L.; Vestal, J.R. Physical and Chemical Correlates of Microbial Activity and Biomass in Composting Municipal Sewage Sludge. Appl. Environ. Microbiol. 1985, 50, 1395-1403. [CrossRef]

28. Kapuinen, P. SE-Structures and Environment. J. Agric. Eng. Res. 2001, 80, 87-97. [CrossRef]

29. Miyatake, F.; Iwabuchi, K.; Abe, Y.; Honda, Y. Effect of High Moisture Content on Temperature and Microbial Activity of Composting Dairy Cattle Manure. J. Jpn. Soc. Agric. Mach. 2007, 69, 48-54.

30. Sommer, S.G. Eco-friendly and efficient management of solid animal manure. In Livestock Housing: Modern Management to Ensure Optimal Health and Welfare of Farm Animals; Aland, A., Banhazi, T., Eds.; Wageningen Academic Publishers: Wageningen, The Netherlands, 2013; pp. 67-107.

31. Eggleston, S.; Buendia, L.; Miwa, K.; Ngara, T.; Tanabe, K. 2006 IPCC Guidelines for National Greenhouse Gas Inventories; Institute for Global Environmental Strategies: Hayama, Japan, 2006. 
32. Habtewold, J.; Gordon, R.; Sokolov, V.; Vanderzaag, A.; Wagner-Riddle, C.; Dunfield, K. Reduction in Methane Emissions from Acidified Dairy Slurry Is Related to Inhibition of Methanosarcina Species. Front. Microbiol. 2018, 9, 2806. [CrossRef] [PubMed]

33. Petersen, S.O.; Olsen, A.B.; Elsgaard, L.; Triolo, J.; Sommer, S.G. Estimation of Methane Emissions from Slurry Pits below Pig and Cattle Confinements. PLoS ONE 2016, 11, e0160968. [CrossRef] [PubMed]

34. Ahn, Y.H. Sustainable nitrogen elimination biotechnologies: A review. Process. Biochem. 2006, 41, $1709-1721$. [CrossRef]

35. Di,H.-J.; Cameron, K.C.; Sherlock, R.R.; Shen, J.-P.; He, J.-Z.; Winefield, C. Nitrous oxide emissions from grazed grassland as affected by a nitrification inhibitor, dicyandiamide, and relationships with ammonia-oxidizing bacteria and archaea. J. Soils Sediments 2010, 10, 943-954. [CrossRef]

36. Wunderlin, P.; Mohn, J.; Joss, A.; Emmenegger, L.; Siegrist, H. Mechanisms of N2O production in biological wastewater treatment under nitrifying and denitrifying conditions. Water Res. 2012, 46, 1027-1037. [CrossRef]

37. National Research Council (NRC). Air Emissions from Animal Feeding Operations: Current Knowledge, Future Needs; National Academies Press: Washington, DC, USA, 2003.

38. Mulbry, W.; Ahn, H. Greenhouse gas emissions during composting of dairy manure: Influence of the timing of pile mixing on total emissions. Biosyst. Eng. 2014, 126, 117-122. [CrossRef]

39. Sharma, B.; Vaish, B.; Srivastava, V.; Singh, S.; Singh, P.; Singh, R.P.; Oves, M.; Khan, M.Z.; Ismail, I.M. An Insight to Atmospheric Pollution- Improper Waste Management and Climate Change Nexus. In Modern Age Environmental Problems and their Remediation; Springer Science and Business Media: Cham, Switzerland, 2017; pp. 23-47.

40. Gilroyed, B.; Hao, X.; Larney, F.J.; McAllister, T.A. Greenhouse Gas Emissions from Cattle Feedlot Manure Composting and Anaerobic Digestion as a Potential Mitigation Strategy. In Understanding Greenhouse Gas Emissions from Agricultural Management; Guo, L., Gunasekara, A.S., McConnell, L.L., Eds.; American Chemical Society (ACS): Washington, DC, USA, 2011; pp. 419-441.

41. Hao, X.; Chang, C.; Larney, F.J.; Travis, G.R. Greenhouse Gas Emissions during Cattle Feedlot Manure Composting. J. Environ. Qual. 2001, 30, 376-386. [CrossRef]

42. Giuliana, D.; Fabrizio, A. The contribution of water soluble and water insoluble organic fractions to oxygen uptake rate during high rate composting. Biodegradation 2006, 18, 103-113. [CrossRef]

43. Peigné, J.; Girardin, P. Environmental Impacts of Farm-Scale Composting Practices. Water Air Soil Pollut. 2004, 153, 45-68. [CrossRef]

44. Joo, H.; Ndegwa, P.M.; Heber, A.; Ni, J.-Q.; Bogan, B.; Ramirez-Dorronsoro, J.; Cortus, E. Greenhouse gas emissions from naturally ventilated freestall dairy barns. Atmos. Environ. 2015, 102, 384-392. [CrossRef] 